How to Cite

Padmiswari, A. A. I. M., Wulansari, N. T., Antari, N. W. S., Damayanti, I. A. M., Indrayoni, P., \& Indrawan, G. S. (2021). The effectiveness of soaking duration on blood cockles (Anadara granosa) with activated charcoal towards reducing metals lead $(\mathrm{Pb})$. International Journal of Health \& Medical Sciences, 4(3), 304-308.

https://doi.org/10.31295/ijhms.v4n3.1756

\title{
The Effectiveness of Soaking Duration on Blood Cockles (Anadara granosa) with Activated Charcoal towards Reducing Metals Lead (Pb)
}

\author{
Anak Agung Istri Mas Padmiswari \\ Institute of Technology and Health Bali, Indonesia \\ Corresponding author email: maspadmiswari@yahoo.com
}

\section{Nadya Treesna Wulansari}

Institute of Technology and Health Bali, Indonesia

Email: nadyatreesna@gmail.com

\author{
Ni Wayan Sukma Antari \\ Institute of Technology and Health Bali, Indonesia \\ Email: sukma.antari91@gmail.com
}

\section{Ida Ayu Manik Damayanti}

Institute of Technology and Health Bali, Indonesia

Email: idaayumanikk@gmail.com

\section{Putu Indrayoni}

Institute of Technology and Health Bali, Indonesia

Email: indrayoniputu.stikesbali@gmail.com

\section{Gede Surya Indrawan}

Udayana University, Indonesia

Email: suryaindrawan@unud.ac.id

\begin{abstract}
Blood cockle (Anadara granosa) is one of the marine biotas that can be used as a bio indicator of the pollution level of sea water. The nature of blood cockle stays in one place because of their slow movement and they are non-selective filter feeders which filter water in order to get food. The use of activated charcoal during soaking is to keep the food safety from blood cockle contaminated with heavy metals. The purpose of this study is to determine the affectivity test of soaking duration on blood cockle (Anadara granosa) and activated charcoal toward reducing metals lead $(\mathrm{Pb})$. This study employed Randomized Complete Design $(R C D)$ using three different soaking periods such as 30 minutes, 60 minutes, and 90 minutes. The samples were analyzed by Inductively Coupled Plasma Emission (ICPE). The parametric data was analyzed with One Way Anova test. The result of the study showed that the soaking duration among 30 minutes, 60 minutes, and 90 minutes in activated charcoal showed significantly different $(P<0.05)$ toward the levels of lead.
\end{abstract}

Keywords---activated charcoal, blood cockle, inductively coupled plasma emission (ICPE), lead, soaking 


\section{Introduction}

Cockles is one of the seafood that is favored by the people of Indonesia. Scallops have a delicious, savory taste and have good nutritional value. The level of cockle's production in Indonesia is quite high so that it is able to meet the needs of the community. Based on data from the Directorate General of Capture Fisheries the value of cockle's production increases every year, the average value of cockle's production in Indonesia from 2004 to 2014 is $3,220.92 \%$. One of the most popular cockles on the island of Bali is the blood cockles (Anadara granosa). Blood cockles are widely sold because they have economic commodities that are spread in almost all Indonesian waters (Sudarmawan et al., 2020). Utilization of cockles apart from being a source of animal protein, cockles is also used as an ecological indicator, namely as an indicator of pollution in the environment (Indrawan \& Putra, 2018).

Blood cockles are bioindicators of environmental pollution levels because they have properties that stay in one place for a long time, slow mobility, and are filter feeders (Mawardi \& Sarjani, 2017). This causes the blood cockles to be susceptible to water and sediment pollution, especially heavy metals that are accumulative in the cockles's body (Herawati \& Soedaryo, 2017). Blood cockles can accumulate heavy metals in their bodies if they live in waters contaminated with heavy metals (Hendrarto \& Hadiyarto, 2011). Heavy metal levels found in waters are generally caused by the waters being polluted by waste from industrial activities or household waste that is dumped into rivers, estuaries or the sea (Andayani et al., 2020).

The requirements of the Indonesian National Standard on food quality and safety of cockles stipulate that the limit for heavy metals contained in cockles should not be more than $1 \mathrm{ppm}$. The high public interest in consuming seafood such as blood cockles has made some processors think about how to reduce the heavy metal content in cockles so that the cockles consumed remains within safe limits (Wirawan, 2016). There is one method in reducing heavy metals in blood cockles is to include an adsorbent (activated carbon or activated charcoal) in the processing so that heavy metals in blood cockles will be absorbed by the adsorbent (Rachmawati et al., 2013).

Activated charcoal is charcoal that has undergone an activation process to increase the surface area through opening the pores so that the adsorption power can be increased. The wider surface of activated charcoal causes its adsorption power to gas or liquid to be higher. Several studies on the use of activated charcoal have also been carried out, such as the use of activated charcoal to reduce histamine levels in pindang tuna (Subaryono et al., 2017). The use of activated charcoal to reduce metals contained in factory waste was also carried out by Wirawan (2016), and the use of modified activated charcoal from the shell of Jatropha curcas as an adsorbent of copper metal $(\mathrm{Cu})$, removal of heavy metal cadmium $(\mathrm{Cd})$ in water with activated charcoal from the shell coconut (Gaikwad, 2004). The last study was also conducted by Rachmawati et al. (2013), using the method of boiling activated charcoal on blood cockles with a time of 20 minutes, 25 minutes and 30 minutes. From the results of this study, it was found that the boiling time for 30 minutes reduced the metal content in blood cockles.

Based on the methods of reducing heavy metal content, research innovations were carried out by immersing cockles using activated charcoal. The difference in this research is using activated charcoal immersion method with different immersion time. So it is expected that the duration of immersion as an alternative to reduce levels of heavy metal content such as lead $(\mathrm{Pb})$ in the body of blood cockles. In addition, the purpose of this study is to monitor environmental pollution, food safety, and exposure to lead $(\mathrm{Pb})$ in humans (Pan \& Tangratanavalee, 2003; Mirsadeghi et al., 2011).

\section{Methods}

This study used a Completely Randomized Design (CRD) model with 1 control group (without soaking with activated charcoal) and 3 treatment groups with 5 replications each in the sample. This study used 200 cockles obtained from the Kedonganan Market, Badung Bali. The blood cockles were washed to remove dirt and mud on the shells. The concentration of activated charcoal used was obtained from the best concentration of previous studies, which was $5 \%$ by weight of blood cockles (Rachmawati et al., 2013). The activated charcoal used is made from coconut shells that have been burned and then mashed. The immersion process begins with the inclusion of blood cockles and activated charcoal simultaneously to be immersed in distilled water with a ratio of the weight of the shells to the volume of water is 1:2 (Rachmawati et al., 2013). Immersion was carried out for 30 minutes for Treatment 1, 60 minutes for Treatment 2, and 90 minutes for Treatment 3 with one immersion each (Davenport \& Wong, 1986; Mirsadeghi et al., 2013).

The blood cockles that had been soaked were analyzed using the wet ashing method and analyzed using an ICPE (Inducted-vely coupled plasma emission) device. The measurement of the metal content of lead $(\mathrm{Pb})$ using the ICPE (Inductedvely coupled plasma emission) tool and the results of the analysis of the metal content of lead $(\mathrm{Pb})$ will be compared with the quality standards of the Food and Drug Supervisory Agency (BPOM) (Akib, 2009). Data analysis 
was carried out quantitatively using a computer statistical program (SPSS 22.0 for Windows). To test the normality of the data, the Kolmogorov-Smirnov test was used. To see the homogeneity of variance, it is done by Leven's Test. To see the effect of the treatment, the One Way Anova test was carried out. If there are significant results, it is continued with Duncan's multiple distance test with the degree of confidence used is 5\% ( $<$ < 0.05$)$ (Mozammel et al., 2002; Mor et al., 2007).

\section{Results}

The effect of immersing blood cockles using activated charcoal on the metal content of lead $(\mathrm{Pb})$ can be seen in Table 1 The results of statistical analysis of metal content showed that there was a significant difference $(\mathrm{P}<0.05)$ between control and treatment.

Table 1

Lead metal content (ppm) of blood cockles soaked with activated charcoal

\begin{tabular}{cc}
\hline Immersion Time & Lead Metal $(\mathrm{Pb})$ \\
\hline Control & $0,96 \pm 0,11^{\mathrm{a}}$ \\
30 minutes & $0,63 \pm 0,03^{\mathrm{b}}$ \\
60 minutes & $0,46 \pm 0,01^{\mathrm{c}}$ \\
90 minutes & $0,30 \pm 0,05^{\mathrm{d}}$ \\
\hline
\end{tabular}

Significant differences in the metal content of lead at 30 minutes, 60 minutes and 90 minutes showed that soaking blood cockles using activated charcoal could reduce the lead metal content in blood cockles. This is caused by the content of activated charcoal which can absorb the metal content of lead in cockles. According to Rachmawati et al (2013), that activated charcoal has absorption in wide pores and has adsorption power to gases or liquids. In addition, the long immersion time also affects the decrease in lead metal content. The longer the process of immersing blood cockles with activated charcoal, the longer the diffusion process can take place. Trihandaru et al. (2012), which states that the diffusion process is the random movement of molecules of a substance that results in the movement of effective molecules from high concentrations to low concentrations.

The length of time for soaking cockles with activated charcoal can also be caused by the adsorption process of the activated charcoal. This is reinforced by Wirawan (2016), which states that a sufficient length of contact time is required for activated charcoal to be able to adsorb metals optimally. The longer the contact time, the more metal is adsorbed because the more opportunities for activated charcoal particles to come into contact with the metal. This causes more metal to be bound in the pores of the activated charcoal. The long soaking time can also cause the pores on the surface of the activated charcoal to attract metal ions in the cockles but in different amounts in each cockles depending on the type and size. According to Syauqiah et al. (2011), absorption using activated carbon is the most effective way to reduce the heavy metal content in cockles. The adsorption process on activated charcoal can occur through 3 basic stages, namely: the substance is bound on the outside, then moves towards the pores of the charcoal, and finally the substance collects on the inner wall of the charcoal. In the initial process, the Pb content in cockles is bound to the outside of the activated charcoal. The adsorbate adheres to the surface by forming chemical bonds which are covalent bonds. Furthermore, the covalent bonds move towards the pores of the activated charcoal. Due to the presence of chemical bonds on the surface of the adsorbent, a layer will be formed where the layer will inhibit the subsequent adsorption process by the adsorbent so that the effectiveness is reduced and the substance collects onto the inner wall of the charcoal (Syauqiah et al., 2011).

The best lead metal content in this study was obtained at an immersion time of 90 minutes, which was $0.30 \mathrm{ppm}$ which already met the safe limit for lead metal content found in mussel meat. In the control, the 30-minute treatment and the 60-minute treatment were actually still within safe limits compared to the metal content of lead and safe for consumption by the public, but the best results were obtained at 90 minutes of immersion. SNI explains that the safe limit of lead content in mussel meat is $1 \mathrm{ppm}$. This value is far below the threshold value of the SNI quality standard, so that the cockles is still suitable for consumption. In addition, the mussels that were used as controls in this study contained lead heavy metals that were still below the threshold, so that the cockles in the Kedonganan market were still safe for consumption. The decrease in lead $(\mathrm{Pb})$ content is also thought to be related to the immersion process where the immersion process itself can also reduce the lead metal content in cockles. This is in line with research, which states that soaking cockles in a holding tank can reduce the heavy metal content in the body of mussels (Sandi et al., 2017; Sutapa et al., 2020). 
In addition to the soaking method, there are several other methods that can also be used to reduce the heavy metal content in mussel meat. However, research on methods to reduce heavy metal content in mussel meat still needs to be further developed using natural, cheaper and easily obtained materials, this is considering the high public preference for mussel meat and the increasing tendency of pollution of a body of water by heavy metals due to development population and industry (Chan et al., 2002; Bettinelli et al., 2000).

\section{Conclusion}

The immersion time of blood cockles (Anadara granosa) using activated charcoal for 30, 60 and 90 minutes can reduce the metal content of lead $(\mathrm{Pb})$ (Liu et al., 2005; Li et al., 2002).

\section{References}

Andayani, A., Koesharyani, I., Fayumi, U., Rasidi, R., \& Sugama, K. (2020). Akumulasi Logam Berat Pada Kerang Hijau di Perairan Pesisir Jawa. OLDI (Oseanologi dan Limnologi di Indonesia), 5(2), 135-144.

Bettinelli, M., Beone, G. M., Spezia, S., \& Baffi, C. (2000). Determination of heavy metals in soils and sediments by microwave-assisted digestion and inductively coupled plasma optical emission spectrometry analysis. Analytica Chimica Acta, 424(2), 289-296. https://doi.org/10.1016/S0003-2670(00)01123-5

Chan, M. K., Othman, R., Zubir, D., \& Salmijah, S. (2002). Induction of a putative metallothionein gene in the blood cockle, Anadara granosa, exposed to cadmium. Comparative Biochemistry and Physiology Part C: Toxicology \& Pharmacology, 131(2), 123-132. https://doi.org/10.1016/S1532-0456(01)00293-9

Davenport, J., \& Wong, T. M. (1986). Responses of the blood cockle Anadara granosa (L.)(Bivalvia: Arcidae) to salinity, hypoxia and aerial exposure. Aquaculture, 56(2), 151-162. https://doi.org/10.1016/0044-8486(86)900244

Gaikwad, R. W. (2004). Removal of Cd (II) from aqueous solution by activated charcoal derived from coconut shell. Electron J Environ Agric Food Chem, 3(4), 702-709.

Hendrarto, B., \& Hadiyarto, A. (2011). Bioaccumulation of heavy metals lead ( $\mathrm{Pb}$ ) and zinc ( $\mathrm{Zn})$ in blood cockles (Anadara granosa) and mangrove shells (Polymedosa bengalis L.) in Kendari Bay (in Bahasa Indonesia). $J$ Environmental Science, 9, 45-50.

Herawati, D., \& Soedaryo, S. (2017). Pengaruh Perendaman Kerang Darah (Anadara Granosa) dengan Perasan Jeruk Nipis terhadap Kadar Merkuri (Hg) dan Kadmium (Cd). Jurnal SainHealth, 1(1), 30-35.

Indrawan, G. S., \& Putra, I. N. G. (2018) Konsentrasi Logam Berat (Pb, Cu, Cd, Zn) Pada Air Dan Sedimen Di Perairan Serangan, Bali Heavy Metal Concentration $(\mathrm{Pb}, \mathrm{Cu}, \mathrm{Cd}, \mathrm{Zn})$ In Water And Sediment In Serangan Waters, Bali.

Li, Y. H., Wang, S., Wei, J., Zhang, X., Xu, C., Luan, Z., ... \& Wei, B. (2002). Lead adsorption on carbon nanotubes. Chemical Physics Letters, 357(3-4), 263-266. https://doi.org/10.1016/S0009-2614(02)00502-X

Liu, Y., Liang, P., \& Guo, L. (2005). Nanometer titanium dioxide immobilized on silica gel as sorbent for preconcentration of metal ions prior to their determination by inductively coupled plasma atomic emission spectrometry. Talanta, 68(1), 25-30. https://doi.org/10.1016/j.talanta.2005.04.035

Mawardi, M., \& Sarjani, T. M. (2017). The quality of Anadara granosa based on Cadmium metal test in the coastal area of Langsa in Aceh. Jurnal Biologi Edukasi, 9(1), 3943.

Mirsadeghi, S. A., Zakaria, M. P., Yap, C. K., \& Gobas, F. (2013). Evaluation of the potential bioaccumulation ability of the blood cockle (Anadara granosa L.) for assessment of environmental matrices of mudflats. Science of the Total Environment, 454, 584-597. https://doi.org/10.1016/j.scitotenv.2013.03.001

Mirsadeghi, S. A., Zakaria, M. P., Yap, C. K., \& Shahbazi, A. (2011). Risk assessment for the daily intake of polycyclic aromatic hydrocarbons from the ingestion of cockle (Anadara granosa) and exposure to contaminated water and sediments along the west coast of Peninsular Malaysia. Journal of Environmental Sciences, 23(2), 336345. https://doi.org/10.1016/S1001-0742(10)60411-1

Mor, S., Ravindra, K., \& Bishnoi, N. R. (2007). Adsorption of chromium from aqueous solution by activated alumina and activated charcoal. Bioresource Technology, 98(4), 954-957. https://doi.org/10.1016/j.biortech.2006.03.018

Mozammel, H. M., Masahiro, O., \& Bhattacharya, S. C. (2002). Activated charcoal from coconut shell using $\mathrm{ZnCl} 2$ activation. Biomass and Bioenergy, 22(5), 397-400. https://doi.org/10.1016/S0961-9534(02)00015-6

Pan, Z., \& Tangratanavalee, W. (2003). Characteristics of soybeans as affected by soaking conditions. LWT-Food Science and Technology, 36(1), 143-151. https://doi.org/10.1016/S0023-6438(02)00202-5 
Rachmawati, R., Ma'ruf, W. F., \& Anggo, A. D. (2013). Pengaruh lama perebusan kerang darah (Anadara granosa) dengan arang aktif terhadap pengurangan kadar logam kadmium dan kadar logam timbal. Jurnal Pengolahan dan Bioteknologi Hasil Perikanan, 2(4), 41-50.

Sandi, N., Ardana, A. G., Parwata, M. Y., \& Teresna, W. (2017). Effect of relative humidity on expenditure of body fluids and blood pressure when exercise. International research journal of engineering, IT \& scientific research, 3(2), 114-122.

Subaryono, S., Ariyani, F., \& Dwiyitno, D. (2017). Penggunaan Arang Untuk Mengurangi Kadar Histamin Ikan Pindang Tongkol Batik (Euthynnus affinis). Jurnal Penelitian Perikanan Indonesia, 10(3), 27-34.

Sudarmawan, W. S., Suprijanto, J., \& Riniatsih, I. (2020). Abu Cangkang Kerang Anadara granosa, Linnaeus 1758 (Bivalvia: Arcidae) sebagai Adsorben Logam Berat dalam Air Laut. Journal of Marine Research, 9(3), 237-244.

Sutapa, G. N., Trisnawati, N. L. P., \& Kasmawan, I. G. A. (2020). Survival of White Blood Cells of Mice (Mus Muscullus L) Against Adaptation Dose of Gamma Co-60 Radiation. International Research Journal of Engineering, IT and Scientific Research, 6(6), 31-36.

Syauqiah, I., Amalia, M., \& Kartini, H. A. (2011). Analisis variasi waktu dan kecepatan pengaduk pada proses adsorpsi limbah logam berat dengan arang aktif. Info-Teknik, 12(1), 11-20.

Trihandaru, S., Widyayanti, A., Rachmawati, S., \& Toenlioe, B. S. (2012). Pemodelan dan Pengukuran Difusi Larutan Gula dengan Lintasan Cahaya Laser. Prosiding Pertemuan Ilmiah XXVI HFI Jateng \& DIY, 27-30.

Wirawan, T. (2016). Pemanfaatan arang aktif dari tempurung jatropha curcas 1. Yang Termodifikasi Sebagai Adsorben Logam Tembaga (cu). Jurnal kimia mulawarman, 8(1). 